\title{
WINNING THE BATTLE OF AUTHORITIES: THE MUSLIM DISPUTES OVER THE COVID-19 PANDEMIC PLAGUE IN CONTEMPORARY INDONESIA
}

\author{
Masdar Hilmy \\ State Islamic University (UIN) Sunan Ampel Surabaya \\ masdar.hilmy@uinsby.ac.id \\ Khoirun Niam \\ State Islamic University (UIN) Sunan Ampel Surabaya \\ khoirunniam@uinsby.ac.id
}

\begin{abstract}
Scholarly works on the way Indonesian Muslims perceive and respond to a pandemic-including Covid-19-have left an untouched theoretical gap. Works on pandemics or plagues mostly consist of sporadic and preliminary brief reflective pieces. This article endeavors to fill the academic gap concerning this theme. This article seeks to portray the dynamics of the religious disputes among Indonesian Muslims about the Covid-19 pandemic that affects the entire world. Using a qualitative method of analysis based on data derived from various sources such as social and non-social media like newspapers and such - the paper argues that the public sphere serves as an open stage to contest ideas among society members where ideas based on sacred and scientific texts are publicly tested. While the majority of Muslims comply with the official disease prevention protocol,
\end{abstract}


others resist it on the grounds that the protocol might undermine the spirit of Islam and the quality of the faith. Their resistance to some degree indicates the dominance of the deductive paradigm that religious authority is endangered in the public sphere.

Keywords: Islam, Covid pandemic, religious authority, deductive reasoning, inductive reasoning.

\section{A. Introduction}

So far, no scholarly works have been published that seriously study how Indonesian Muslims perceive and approach a disaster such as the present Covid-19 pandemic. Some works, of course, have been published but they are sporadic and contain brief reflections about the plague (Fathurrahman, 2020; Jahroni, 2020; Niam, 2020). Looked at more closely, what underlies the Indonesian Muslims' response in the debate in the public sphere is the intellectual and theological discourse on how their understanding of the pandemic has gradually transformed from a fatalistic, God-centered attitude towards a more science-based one. In spite of this persistent, fatalistic God-centered attitude, Indonesian Muslims in general have evolved into accepting a more diversified understanding of the pandemic. As a result, there is a wide range of public discourse among the Muslim community on how the pandemic is perceived, the manner it deals with it, and what paradigmatic framework is used in confronting the pandemic, and so forth.

The series of remarks made above have not been given adequate attention in serious academic discussions. This article seeks to portray the dynamics of the public debate 
among Indonesian Muslims on the Covid-19 pandemic as it has been sweeping all over the world in early 2020. It uses a qualitative analysis based on data offered by prominent Muslims taken from various sources such as social and other media. Prior to presenting the public discourses regarding the Covid-19 pandemic, this article starts with a brief overview on non-pandemic plagues in Muslim history. This historical overview is followed by an account of how Muslim organizations such as Muhammadiyah and the Nahdlatul Ulama (NU), and the Majelis Ulama Indonesia (Indonesian Council of Muslim Scholars, MUI) responded to the plague, before it continues to analyze the public debate from the perspective of religious authority.

In addition to having caused severe devastation in almost all aspects of life, the Covid-19 pandemic has also been an "academic blessing in disguise" in the sense that it stimulates a plethora of studies and scholarly works. While some of these studies analyze the plague from the educational perspective (Agustin et al., 2020; Atsani, 2020; Mansyur, 2020; Napitupulu, 2020; Putra, 2013), others put their emphasis on its social and economic dimensions (Iskandar et al., 2020; Sumarni, 2020). There are, of course, various recent studies that analyze the present pandemic from a religious and Islamic point of view (Darmawan et al., 2020; Kuipers et al., 2020; Mushodiq \& Imron, 2020). These works, however, do not specifically address the issue of the contest of authority among Indonesian Muslims in the way they perceive the pandemic. This article, therefore, tries to fill the theoretical gap left by these works by arguing that the pandemic has resulted not only in different perspectives about it among 
different Muslim figures but also in an open contest for authority among them.

This article argues that the public debate over the Covid-19 pandemic can be seen to represent a battle for authority between inductive scientific reasoning as represented by science on the one hand, and the deductive textual approach as represented by religion. Despite the persistence of deductive reasoning, inductive reasoning has finally won the debate by the state-sponsored adoption of medical protocols for Covid-19 prevention. In the long-run, inductivized religion seems to have been a realistic solution in compromising the never-ending battle between the two ways of reasoning in response to the Covid-19 pandemic.

\section{B. Pandemics in the history of Islam}

Throughout history, plagues have afflicted Muslim communities. The first deadly plague wiped out Muslims during the reign of Umar Ibn Khattab, the Prophet's Companion and the second Caliph. Many of the Prophet's Companions were the victims of this plague that occurred in $17 \mathrm{H} / 638 \mathrm{CE}$ or $18 \mathrm{H} / 639 \mathrm{CE}$ (Al-Suyuthi, 1997) and claimed no less than 25.000 lives (Dols, 2019). In the history of Islam, this plague is known as Tha'un 'Amwas. The term 'Amwas is taken from the site where the plague first occurred which is located in present-day Syam or Syria. It not only struck 'Amwas, but spread out to neighboring Iraq and Egypt. It started with a famine in Syria that extended up to Palestine where the population was subsequently exposed to the plague. Plagues are usually the result of deteriorating human conditions that invite plague-carrying animals such as rats to places where food is stored in the people's houses (Dols, 2019). 
Ibn Hajar al-Asqalani (Al-Asqalani, 1993) (d. $852 \mathrm{H}$ ) is among the generation of Muslim scholars (ulama) that lived during a pandemic and his three daughters fell victim to it. To express his anguish about this, he wrote a treatise for the remembrance of the plague entitled Badhl al-Ma'un Fi Fadhl alTha'un (Exerting All Help Amidst the Plague/Tha'un) (Byrne, 2012). In this work, he said that a horrible plague hit Syria in $794 \mathrm{H} / 1392$ CE (Al-Asqalani, 1993). In order to confront the spread of the plague, Muslims gathered in an outdoor space to say their prayers and the crowd and their superiors (alkaba'ir) went outdoors in droves. They started to say their prayers together but, after their prayers the plague became increasingly worse and claimed even more deaths, while before the people gathered to say their prayers, the scale of the plague was still limited (Joseph Patrick Byrne, 2004; Cantor, 2001; Naphy \& Spicer, 2000; Person, 2010; Scott \& Duncan, 2004).

A similar plague also hit Cairo, Egypt in 833 H/1430 CE. and the Muslim response to it was the same as that in Syria: mass public prayers in an open space. As in Syria, the situation deteriorated and the death toll increased as the plague hit the attendants to the prayers. As quoted by Ibn Hajar:

"The death toll was only 40 people prior to praying. The crowd went out in droves into an outdoor space on the $4^{\text {th }}$ Jumadil Ula, after they had been asked to fast for three days in advance like what they would have done prior to prayers asking for rain (istisqa) and they said their prayers and went home. After one month had passed (since the mass public prayer), the death toll in one day reached one thousand people in Cairo and increased exponentially since then." (Nuha, 2020). 
What Ibn Hajar recorded indicates that Muslims have known plagues since the beginning of their history. The deaths caused by these plagues were also countless. More importantly, the efforts to expel the plagues were always the same: outdoor mass public prayers where contagion among them was unavoidable. As a result, the mass public prayers did not make them better; it even made the plague worsen. Considering that this curing method did not offer any solution, other efforts should have been made in order not to repeat the same mistakes all the time. This repetition might have been caused by a lack of shared knowledge regarding the contagious effect of a plague. As a result, history repeated itself: every plague resulted in a massive death-toll among Muslims (Stearns, 2008).

The 'Amwas plague is one of the most memorable events in the history of plague prevention in Muslim history because it directly affected how Muslims responded to later plagues. Muslims needed a theologically sound justification in their responses to each plague in order to give them a sense of authentic "self." They felt the need to be well-equipped with a standardized code of religious conduct derived directly from the two most authoritative sources in Islam, i.e. the Qur'an and the Prophetic Hadith. By and large, there are three Islamic principles upon which most of the Muslims base their response to a plague: (1) a plague is a heavenly blessing and when Muslims die due to a plague they are considered martyrs while a plague is a punishment for non-Muslims; (2) Muslims shall not enter a plague-affected land leave plague infested regions; and (3) a plague cannot be contagious since all diseases come from Allah (Dols, 2019). 
The three principles continue to invite controversies and public dispute each time a plague comes upon Muslims. As has been demonstrated throughout Muslim history, especially during the 'Amwas plague, the public disputed over the three principles because it was simply unacceptable that the deadly plague is a heavenly blessing and dying from it would make one a martyr, the tendency to stay away from it and the devastating effects it caused. Therefore, it is simply unrealistic to assume that these principles represent the Muslims' response to plagues, either during the Middle Ages or nowadays. These principles, nevertheless, came to be established as the normative grounds for the Muslim community in its response to a plague.

With regards to the first principle, some Muslims consider that a plague is indeed a heavenly punishment $(a d z a b)$. This notion is deeply rooted in the Jewish and Christian theological heritage. In this context, a plague tends to be regarded as God's admonishment and punishment for the people's sins and violations of moral conduct (Meri, 2005). For example, Muslims believe that the plague that hit Damascus in Syria was a punishment for the sins the people had committed, namely the rampant drinking of forbidden (haram) alcoholic beverages. Based on Umar's command, Abu Ubayd lashed them with the rules in Islamic law (Al-Suyuthi, 1997). The belief that a plague is a heavenly blessing and brings martyrdom for Muslims was mostly accepted among Muslims without dispute.

Apart from these viewpoints, it is believed that it is God Who sends the plague and therefore humans have no choices but to accept it. This belief can also be found in the discussion 
of the second principle; Whether or not people chose to remain in an area hit by the plage also does not change their fate because God has determined the moment of death for each person. This follows Abu Musa al-Asy'ari's argument regarding a plague (Kathir, 1985). It is reported that when some of Abu Musa's companions came to his house in Kufah, he asked them to stay outside because there was a member of his family inside who had the plague and he urged them instead to go to an open space or a city garden. The point, according to Abu Musa, was that Muslims cannot be blamed if they flee from the plague because God has determined the moment for their deaths (Kathir, 1985). Because of this, Abu Musa supported Umar's decision to flee from a plague-stricken land whereas Abu Ubaydah opted to stay in Damascus. Among the Prophet's Companions who died because of the 'Amwas plague were Abu Ubaydah himself, Abu Yazid ibn Abi Sufyan, Muadz bin Jabal and his son (Dols, 2019). Because of their deaths, Umar appointed Mu'awiyah ibn Abi Sufyan as Commander in Syria and thus gave him the opportunity to build up his power.

Besides the 'Amwas plague, there was another series of pandemic plagues that swept the Muslim lands in the Middle East, including the "violent plague" (Dols, 2019) which got its name because it came out of Baghdad in 69 H/688-689 CE like a flood. The next massive plague was in $87 \mathrm{H} / 706 \mathrm{CE}$ and called the "girl plague" (al-Fatayat, lit. means "girls"). According to Alfred von Kremer - as quoted by Dols - there has been a series of massive outbursts of the plague sweeping out of most parts of the Middle East in 448-449 H/1056-1057 CE (Dols, 2019). Also, as Ibn Hajar maintained, a deadly outburst of the plague hit Samarkand and Balkh that claimed more than 6,000 lives 
per day (Dols, 2019). In addition, in $455 \mathrm{H} / 1063 \mathrm{CE}$ the plague hit Egypt and spread out to Europe. In 469 H/1076-1077 CE, a massive plague also hit Syria (Dols, 2019).

In many works on the history of Islam and the plague, scholars argue that in their response to a plague, Muslims in general tended to be more theologically fatalistic compared to their counterparts in Judaism and Christianity (Varlik, 2015). While based on scientific investigation the Jewish and Christian population believed the theory of contagion, most Muslims did not. As a result, Muslims were not urged to flee from plague-infected lands on the grounds that it was not contagious but a heavenly blessing and death caused by the plague brought martyrdom, while for non-Muslims it was a heavenly punishment. People with viewpoints that deviated from established orthodoxy were judged to be heretics and they were punished a for their beliefs. Conversely, Christians tended to believe the opposite namely that one had to flee from plague-inflicted land because a plague is contagious and when they insisted on staying, they ran the risk of endangering their own lives and those of others (Dols, 2019).

In the history of Islam, one Muslim scholar's religious viewpoint regarding the plague differed from that of the established orthodoxy. This scholar is Lisan al-Din Ibn alKhatib (d. $774 \mathrm{H} / 1374 \mathrm{CE}$ ), a deeply-learned and prolific figure in Muslim Granada in Spain (Stearns, 2009). He wrote a treatise on the plague called "Black Death" in which he asserts that it is contagious. Even though his opinion contradicted Muslim established understanding, he had empirical proof to support his argument. Because of his oppositional attitude toward mainstream orthodoxy, the local authorities 
consequently punished him as a heretic and he was sentenced to death. According to some historians, the general Muslim viewpoint on the plague tends to be fatalistic and accepts the anti-contagion theory. Al-Khatib is among the few who risked his life for his belief against established orthodoxy for which he was killed 25 years after the Black Death (Stearns, 2009).

Islamic scholarship, however, did develop and change over time. Later generations of Muslim scholars re-examined Al-Khatib's viewpoints that his contemporary coreligionists regarded as heretical, as can be read in $15^{\text {th }}$ century scholarly works on fiqh (Islamic jurisprudence). Al-Khatib's accusation of having been a heretic, therefore, might well have been politically inspired (Conrad, 2017; Perho, 1997). It is also noteworthy that in spite of differences among particular religious communities in response to the plague, the communities of the Jews, Christianity and Islam in general shared common knowledge on the plague, with special reference to their response to the Black Death (Stearns, 2009).

\section{Public Disputes over the Covid-19 Pandemic}

When coming into the public debate, the Covid-19 pandemic is perceived differently among Indonesian Muslim figures and organizations. By and large, the debate can be classified into thematic points as follows.

\section{Plague as Heavenly Punishment}

In Indonesia, the Covid-19 pandemic has invited a variety of responses in the public sphere including one that regards it as the punishment of God for the sins conducted by humans. Anton Tabah, a board member 
of the Indonesian Council of Muslim Scholars (Majelis Ulama Indonesia/MUI), for instance, is a member of this camp. He argues that the Covid-19 pandemic is God's punishment to China because of the atrocities and injustice it perpetrates to the Uyghur fellow Muslims (Safari, 2020). Some even go further by maintaining that the pandemic represents Ababil, the avian troops God sent down to destroy His enemies when the 'Elephant troops', led by King Abrahah, wanted to destroy the Ka'bah (the House of Allah). They think that this time, God sent down the Ababil in the form of the Coronavirus pandemic to destroy China in retaliation of what it is doing to the Uyghur Muslims (Zaki, 2020).

A similar viewpoint was espoused by Habib Novel Chaidir Hasan Bamukmin, one of Habib Rizieq Syihab's Islamic Defenders Front followers and the Chairman of the Media Center of the Brotherhood of the 212 Alumni. In addition to God's punishment to what China is doing to the Uyghur Muslims, Novel believes that God also sent down the Covid-19 pandemic as a punishment for the atheism adopted by the majority of the Chinese people (Pojoksatu, 25 January 2020). Novel said that it must be acknowledged that China is a new global power able to challenge the United States of America (USA), the world's leading super power, but its power has made China arrogant. By sending the pandemic and causing it to claim tens of thousands of Chinese lives, God sent the message to the Chinese that He exists.

Ustadz Abdus Shomad (UAS) has also been giving thought to the spread of the pandemic that first broke out 
in a traditional Market in Wuhan. According to him, the outbreak of the virus cannot be seen in isolation from the Chinese habit of consuming raw meat, un-slaughtered animals and the meat of wild animals. He further argues that the fact that the virus has not contaminated Uyghur Muslims is not by accident " (Sean, 2020), but proof that Allah is protecting the Uyghur Muslims so that they are not affected by the virus. Allah has sent his troops, i.e. the Covid-19 pandemic to protect the Uyghur Muslims. He further states that "Allah indeed loves this ummah (the Muslim community): The ummah has lost its power, the ummah has lost the Caliph (khalifah), the ummah has lost its Sultanate. The only thing it can do is reading the Qur'an and uttering prayer (dhikr) recitation. But Allah is still compassionate and Allah helps His servants with His troops. His last troops are called Corona (Sean, 2020). He said that the Uyghur Muslims are immune to the Coronavirus because of to their habit to do the ablution (wudlu). The virus will not touch people who consistently keep themselves clean. They do not consume haram meat, raw meat, and blood, because blood may contain the virus. According to UAS, when one applies the teachings of Islam, Allah's assistant will come (Sean, 2020). In other words, for UAS, the key to Muslim immunity is living according to Islamic teaching in daily life.

\section{The Plague as Catastrophe}

Apart from those who consider the coronavirus as a heavenly punishment, there is also a segment of Muslims who regard the virus as a catastrophe. Among those who 
hold this assumption is Nasaruddin Umar, the grand Imam (Imam Besar) of the Istiqlal Mosque in Jakarta. He rejects the virus-as-punishment adage, but sees it as a catastrophe or a heavenly test (bala') (Republika, 13 March 2020). In his opinion, the Prophet has prayed for his ummah to be away from all kinds of adzab or punishment. In his argument, the heavenly punishment is only meant for non-believers (kafir) and in this context, the term ' $k a f i r$ ' is understood as both denotatively (nonMuslims) and connotatively (those who disregard Allah's blessings). In his opinion, therefore, there are no more heavenly punishments for Muslims because the Prophet has assured Allah's forgiveness for them.

Similar to what Nasaruddin has argued, KH. Said Aqil Siradj, the General Chairman of the NU, argues that the pandemic is a humanitarian test (Kalam.sindonews.com, 30 March 2020). In his opinion, scientists and religionists (Muslim scholars) share the same responsibility in finding a solution to end the pandemic. Both can complement each other and not be in conflict. While the scientists seek to understand God's creatures, religionists try to find out the relation between God and His creatures. He said that "the scientists investigate anything from the large cosmos to the smallest virus such as Covid-19. Religionists help to give meaning to the most profound human emotion in order to be connected to the Gentlest (al-Halim) as well as the Softest (al-Lathif)" (Rochim, 2020). That being so, there is not much difference between scientists and religionists. Many scientists stay focused on what they investigate and disregard that God's creatures are the 
objects of their investigations while others also believe in the abstract things behind the working framework of the cosmos. In his argument, "the last group consists of believing scientists. In dealing with the Covid-19 pandemic, these believing scientists are seeking a vaccine but they also surrender to God in order for Him to provide safety beyond the efforts of human beings" (Rochim, 2020).

\section{Death as Fate}

Some Muslim clerics and preachers (khatib) try to associate the Covid-19 pandemic with death. According to some of them, regardless of the coronavirus pandemic, everyone's death is predetermined. The pandemic should therefore not make anyone, especially Muslims, afraid of the coronavirus and avoid doing their regular prayers in mosques or other houses of worship. In their opinion, there is nothing to be afraid of but Allah. If one is afraid of anything other than Allah, it means that he/she shares God with His creatures (shirk) which is the major sin in Islam. In addition, the more one gives in to fear the more one is susceptible to viruses and, thus, reduces his/her bodily immunity. This argument can be seen, for instance, among the crowd of the Jamaah Tabligh in Makassar which was planning to hold an ijtima' ulama (gathering of Muslim scholars) from 19 to 22 March 2020 but which was cancelled by the local authorities on safety grounds (Wirawan, 2020). According to the committee, the gathering should have been attended by more than 8,000 Jamaah Tabligh followers. The same event is said to have 
been successfully held in Malaysia (27 February-1 March) which was attended by more than 16,000 followers but later served as a major source of coronavirus contagion in the country.

\section{Plague as Political Means and Bioweapon}

Another interpretation for the pandemic is related to politics and power-related issues and argues that it is not merely a matter of health and medicine per se. More than that, it is also about politics. In other words, the coronavirus pandemic is not something that is happening by accident, but by design. Who designed the pandemic? There must be an invisible power that has created the entire pandemic story which in its turn is the result of short-term political and economic interests. KH Agoes Ali Masyhuri, a Provincial Board Member of NU of East Java, is among those who hold this assumption. He maintains that,

"From the existing data, the mortality rate of the coronavirus takes only 3-5 per cent. Due to this reason, which one is dangerous? Should there be anyone say so, I will check (the mental health of) the person. This (description) is based on data. Don't you want to learn to be smart? Why is everything related to the coronavirus exaggerated? Radio, TV, newspapers, magazines (all talk about this). That has nothing to do with the virus, gentlemen! There must be vested interests, namely the trade war between China and the US. One proverb says, when two big elephants are fighting each other, there is one deer dead in-between" (TV9 Official, 2020).

In addition to being politically and economically laden, some educated individuals also assume that 
bioweapons are behind the coronavirus pandemic. Even though not expressed openly in public, one assumption lingers in the minds of some persons, namely the multiplier effect of bioweapons between the US and China (Silva Alhabsy, 2020). The assumption of the role of bioweapons in the pandemic is based on the heated trade competition between these two super powers. The US is assumed to be aware of China's increasingly threatening power that endangers the US's long-established domination on the global market. As a way to undermine China's increasing power, the US is suspected of having sent a secret agent to China to plant that bioweapon there. With regards to biowarfare, some persons assume that the Covid-19 is a leaked Chinese bioweapon that subsequently proved to be disastrous (Kementerian Komunikasi dan Informatika Republik Indonesia, 2020). The leak is assumed to have some relation with the Chinese authorities' incompetence in dealing with bioweapons.

\section{Responses by Muslim Organizations}

Not only individually, Muslim organizations such Muhammadiyah and NU, and MUI and others have also responded to the spread of the Covid-19 pandemic. Muhammadiyah has issued an official declaration (maklumat) consisting the following six points; (1) all activities involving mass attendancy within Muhammadiyah units such as religious gatherings, seminars, meetings, and other social activities are to be postponed, or be held in a limited and strict way or through the use of technology media; (2) ritual activities such as congregational daily prayers and Friday prayers can be 
done in the mosque under the following conditions; (a). Those who are sick are strongly recommended to perform their rituals at home; (b). In an emergency, the Jum'ah prayers can be replaced with Dhuhur prayers at home and congregational prayers can be performed at home; (3). Educational activities within Muhammadiyah and 'Aisyiyah units can be harmonized in line with the government policy either at the central or provincial/district levels coordinated by the Council for Basic and Secondary Education (Majlis Pendidikan Dasar dan Menengah), and the Council for Higher Education Research and Development (Majlis Pendidikan Tinggi Penelitian dan Pengembangan); (4). The management of philanthropic charity and health matters pertaining to Covid-19 should be adapted to the protocols of the Ministry of Health under the coordination of the Supervisory Council for Public Health in tandem with councils, institutions, autonomous organizations, and other philanthropic bodies; (5). The Central Board of Muhammadiyah has founded the Muhammadiyah Covid-19 Command Center (MCCC); (6). All Muhammadiyah members are advised not to go to places where Covid-19 contagion is possible (Santoso \& Aranditio, 2020).

The next step, on 24 March 2020 the Central Board Members of Muhammadiyah issued a public letter regarding the Guidance on Rituals in a Covid-19 emergency situation. The letter includes guidance on ritual amidst the pandemic in line with the legal opinions (fatwa) of Majelis Tarjih dan Tajdid of the Central Board of Muhammadiyah. That guidance includes fasting during Ramadhan, evening prayers (tarawih), and Idul Fitri, in case of the Covid-19 pandemic during the month of Ramadhan and Idul Fitri. That legal opinion on the 
guidance of the rituals, according to a Central Board member of Muhammadiyah, was made after intensive and serious scrutiny by religious experts in this modernist organization based on the sound sources of Islam, the Qur'an and the Prophetic Hadith (Wirawan, 2020). This guidance contains the general direction for Muhammadiyah members towards a unified ritual framework based on the organization's official position.

The following is from the public letter issued by the Central Board of Muhammadiyah regarding the guidance on rituals during the Covid-19 pandemic during Ramadhan and Idul Fitri: (1). Daily prayers are performed at home in order to avoid the spread of Covid-19; (2). Jum'ah prayers are replaced by Dhuhur prayers; (3). The replacement of the sentence hayya 'ala al-shalah (let's go to prayers) in the adzan (call for prayers) by shallu fi rihalikum (let's do the prayers in your vehicle) or shallu fi buyutikum (let's do the prayers at home); (4). Evening prayers (tarawih) are to be said at home; (5). Dispensation for fasting (for not fasting during the day) for medical workers with the responsibility to replace it on other days in accordance with Shari'ah guidance, and; (6). Idul Fitri prayer to be cancelled if the plague persists (Wirawan, 2020)

In response to the plague, NU has also officially issued a letter of instruction to all members of this organization all over the country consisting of the recommendation to comply with all medical protocols released by authoritative institutions such WHO, Ministry of Health and the government-sponsored Covid-19 special taskforce (Satuan Gugus Tugas), etc. (Kendi Setiawan, 2020). In more detail, the instruction consists of the following six items: (1) to comply with the instructions, recommendations, and protocols released by the government 
in response to the Covid-19 pandemic, including its stay-athome and social distancing policy; (2) not to undertake any type of activities involving massive attendancy and crowds; (3) temporarily terminate routine activities such as religious gatherings, Tahlilan (reciting Tahlil together), Diba'an (reciting diba' together), Lailatul Ijtima' (night of gathering), etc. and postpone organizational programs such as conferences, inaugurations, and workshops; (4) ritual activities such as congregational prayers (Jama'ah), Tahlilan, and Dibaan can be held at home; (5) all pesantrens under Rabithah al-Alam alIslami (RMI) are instructed to halt all pesantren activities that involve large numbers of santri (students); (6) To multiply prayers and rituals as instructed in advance by the Central Board of NU (PBNU) and seek refuge from Allah SWT with the hope that the Covid-19 pandemic can be dealt with soon (Kendi Setiawan, 2020).

\section{E. The Clash of Paradigms: Religion or Science?}

In response to the Covid-19 pandemic, the public sphere has suddenly become flooded by public debates. The avalanche of news and narratives uploaded onto social media related to the coronavirus is overwhelming. Based on data presented earlier, there has been a huge number of assumptions and perspectives in response to the Covid-19 pandemic. Democratic rooms provide a huge variety of public perspectives in which each perspective challenges to one other resulting in lively and healthy public discourses on the matter. Among them, the religious perspective in looking at the pandemic occupies the lion-share of the public debate, regardless of other perspectives such as health, socio-political 
issues, culture, and the economy. What is more interesting is the nature of these diverse and conflicting religious perspectives, reflecting also the diversity of Muslims' religious beliefs and knowledge. Therefore, it can be said that the public sphere serves as the stage for contesting ideas.

The public disputes over the Covid-19 pandemic plague represents a battle over arguments and paradigms between the science-based and religion-based poles, despite the presence of overlapping consensus between the two. On the one side, represented by the religionists, the religion-based pole adopts deductive reasoning as the basis of its arguments in justifying its conception on the Covid-19 pandemic and how to deal with it (Hilmy, 2013). Deductive reasoning in this context means employing normative textual arguments derived from the sacred texts in Islam-Qur'anic verses and Prophetic Hadith-to justify its arguments about the Covid-19 pandemic (Dicker, 2004; Greenberg, 2010). What they observe in socio-religious daily life is that people look for justification from both sacred texts. Due to huge variation of perspectives among Muslims, a large variety in understanding about the pandemic arises. As a result, epistemological collision among them is simply unavoidable, especially when their understandings of the pandemic contradicts the established medical protocols for pandemic prevention.

On the other side, the authority of scientists in science and knowledge production represents the inductive way of reasoning. The inductive paradigm uses laboratory testing, evidence-based observation and empirical experiment as its major tools for knowledge and science production (Hilmy, 2013). It means that what the medical and health authorities 
have carried out so far in identifying the Covid-19 pandemic and their efforts in preventing and curing the virus is purely based on inductive and not on deductive processes. Under this construction of reasoning, the pattern of scientific development follows a bottom-up mechanism rather than a top-down one. Even though in many cases both paradigms share a point where they meet, each represents its own epistemology and both paradigms are basically mutually irreconcilable.

Inductive truth can be replicated in different sites and cases whereas deductive truth does not require this replication (Barlow-Jones \& van der Westhuizen, 2017). Because of this difference, deductive truth is not always relevant to specific cases at an empirical level. Often, deductive truth needs to be applied in analyzing a particular unsuited case, which results in an anachronistic situation (Nagel \& Wood, 2005). For example, UAS's statement that the pandemic represents God's heavenly troops to destroy His enemies, namely the government of China, and to protect the Uyghur Muslims, is problematic according to scientific standards. UAS's statement cannot explain why the same virus has inflicted not only China, but has also spread all over the world including to Muslim majority countries such as Saudi Arabia, Iran, Malaysia, Indonesia and so on. Inductively speaking, therefore, all statements regarding the pandemic as heavenly punishment contradicts the empirical fact that it does not only strike nonMuslim-majority countries, but also Muslim-majority ones.

How about other statements in response to the pandemic? The Jama'ah Tabligh, for instance, has stated provocatively that it is not afraid of the coronavirus but of Allah. It is also clear that most of its members disregard the 
medical protocols on Covid-19 prevention such as social distancing. As can be seen from YouTube channel, television, and pictures in news media, they kept moving about in crowds and ignored social distancing. It is therefore no surprise that after their religious gatherings in Malaysia and Jakarta: the outbreak of the virus in Malaysia started in the Tabligh cluster (Wirawan, 2020). After their religious gathering in Malaysia, they planned to have a similar gathering in Gowa, South Sulawesi with more than 8,000 members coming from various Southeast Asian countries. On the way to Gowa, three Tabligh members were infected with the virus when they made a stop-over in a mosque in Kebon Jeruk, Jakarta. As a result, around 300 members of Jama'ah Tabligh have been isolated in the mosque since 26 March 2020 after which the specific Covid-19 pandemic task-force has moved them into a temporary shelter in an ex-athlete housing facility in Kemayoran, Jakarta (Rifa'i, 2020).

The assumption that the coronavirus is the leak of a Chinese bioweapon has been refuted by the Chinese authorities (Ling, 2020). The issue of the coronavirus pandemic as part of biological warfare between China and the US is also unrealistic after the massive outbreak of the same virus in the latter. As per 6 April 2020, the virus has infected 309,254 people in the US, with 9,620 deceased (Covidvisualizer.com, 6 April 2020). Among the pandemic-infected countries, the US had the highest number of victims compared to any other Western country such as Italy with 91,246 active and 15,887 deceased as the second largest number of victims, and Spain with 80,925 active with 12,641 deceased as the third biggest in number (Covidvisualizer.com, 6 April 2020). In view of 
these data, arguing that the coronavirus pandemic is part of biological warfare between China and the US is therefore academically unfounded.

In the history of ideas, the inappropriateness of ideas written in empirical and historical texts is called anachronism (Skinner, 1969). Inappropriateness can take various forms; inappropriateness in meaning, inappropriateness in historical background and socio-cultural context, and so on. For example, labelling the Covid-19 pandemic a heavenly punishment necessitates a contextual relevance between that assumption and the objective condition of the pandemic regardless whether or not the empirical reality represents what the sacred texts say. Therefore, associating the pandemic as heavenly punishment with objective reality is academically unfounded due mainly to the fact that the pandemic swept over not only non-Muslim countries such as China but also Muslim majority ones as Saudi Arabia, Iran, Indonesia, Malaysia, and the like.

Deriving hidden messages from sacred texts deductively is not a simple endeavor. It is not a matter of word choice and proper language that is at stake to justify empirical facts with the spirit of the sacred texts. Rather, it is related to the way to align the meaning and the relevance of the sacred texts' significance with scientific principles. The relevance of everlasting religious messages with empirical facts can be called the principle of conformity or diachronism (Schellenberg, 2013). Religious diachronism, according to Schellenberg (2013), enables religious interpretation to cover visionary and futuristic religious worldviews as well as historical ones. In adapting to the evolutionary development 
of science, religion should not have taken a judgmental position to contemporary theories of science. However, it requires sensibility to foresee its changing future direction and to understand its past, otherwise religion runs the danger of losing the spirit of its age.

\section{F. Towards the Decline of Religious Authority in the Public Sphere?}

The question is, what the future of religious authority in responding to a large-scale pandemic such as Covid-19 is? Is it possible that the Muslim community continues to trust religionists in understanding the pandemic? Or, on the contrary, will religionists lose their religious authority in response to the pandemic and will it be replaced by that of scientists? These questions will continue to arise as a corollary to the pandemic. The same questions also emerged right after the 2004 tsunami hit Aceh which claimed tens of thousands of lives. In the same pattern of religious (deductive) reasoning, the same narratives repeat themselves: the disaster is a heavenly punishment for human sins. Even though other narratives circulate among society, it is not an easy task to offer an all-encompassing narrative that covers both the deductive and the inductive paradigms of religious reasoning.

It is noteworthy, nonetheless, to recognize that Muslims are now undergoing a process of educational mobilization. The Indonesian Muslim community does not consist of a single monolithic homogenous social group. Muslims have diversified in terms of their socio-political, economic, and cultural mobilization that has resulted in the diversification of religious perspectives about how they perceive the pandemic. 
This diversification can easily be found among the so-called "traditionalist" Muslims where the fatalistic response to the pandemic is no longer as dominant as it was several decades ago when almost all of them shared the same religious way of thinking (Ricklefs, 2007). Therefore, in the way its responds to the pandemic, a shared cultural background does not guarantee homogenous viewpoints among the same social cluster.

The pandemic is purely a matter of health which can be approached by rational inductive tools. The intervention of deductive approaches in understanding and analyzing the pandemic can lead to religious anachronism. Therefore, the wise choice for religionists to make is to keep their "distance" and to let professionals deal with it. The situation does not improve when, in order to understand the pandemic, Muslims use deductive arguments that may contradict Covid-19 prevention health protocols. There are indeed many choices between narratives both from the Qur'an and the Hadith in approaching the pandemic. Forcing these narratives to justify the pandemic, however, can be counterproductive to the effect of public policies in working on Covid-19 prevention. It means that the religionists can hand the job of pandemic prevention to those with authoritative expertise such as people from the WHO and the government, scientists, and paramedics.

In the long run, responding to the pandemic appropriately necessitates Muslims to "inductivize" their deductive narratives on the pandemic, diseases and other disasters. Referring to Al-Jabiri's trilogy of Arab reasoning, Arabs have used three systems of reasoning throughout their history: bayani, burhani, and 'irfani (Muhammad Abid Abid Al-Jabiri, 1993). The first, bayani, consists of the black-and-white legal system of thinking 
that tends to be axiomatic. This thinking system of logics is employed in reasoning on legal matters (Shari'ah). The second reasoning, burhani, consists of a rational inductive mode of thinking used in the development of scientific investigation. This reasoning is employed in the development of science and technology and tends to be closely linked to the use of laboratories and experimental methods. This inductive mode of thinking is in line with the scientific spirit of the Enlightenment (Aufklarung). The third type of reasoning is 'irfani, that is the spiritual logics that deals with human beings' spiritual, psychological and metaphysical condition.

Among these three modes of reasoning, only bayani and 'irfani can be made inductive. The bayani mode of reasoning, however, tends to be deductive in nature and is fixed and axiomatic. It is highly likely that the other two modes of thinking, burhani and 'irfani, are to be used as major mechanisms in developing modern science and technology since they use the inductive mode of reasoning. Both can be made concrete in academic processes such as laboratory tests and experimentation. For example, whether a pandemic is contagious needs to be tested in a laboratory, and it does not suffice to just refer to verses from the Qur'an or the Prophetic Hadith (J. K. Stearns, 2011). In other words, the key to turn deductive modes of reasoning into inductive ones is by laboratory tests, experiments, and the like.

The question remains, however, what happens when the results of laboratory tests contradict the verses of the Qur'an and the Prophetic Hadith? What should Muslims refer to? Is it the result of laboratory tests-using the inductive mode of reasoning — or the Qur'an and Hadith—using the deductive way 
of thinking? In attempts to answer this question, Muslims are not to be trapped in a judgmental attitude to the question of the validity of Qur'anic verses and the Hadith as it may undermine the ummah's trust. In the historical perspective, each verse of the Qur'an and every Hadith of course has its own contextual explanation (asbab al-nuzul for the Qur'an and asbab al-wurud for Hadith). It may be safer to put scientific narratives in a different position vis-à-vis the Qur'an and the Hadith. Let them speak with their own languages and worldviews to enable them to respect one another and not to interfere with each other. In this context, let us not forget that both the Qur'an and the Hadith have their own secrets and contexts. Let Muslim scholars refer to both sources in an appropriate way according to their own respective historical contexts.

\section{G. Conclusion}

From the description above, it can be summed up that in the history of Islam, the way Muslims respond to the present Covis-19 pandemic is not new. The Muslim community has gone through several waves of plagues since its formative period. During the period of Umar ibn Khattab, the first plague called 'Amwas inflicted Muslim community in Syria and it invited public debate among Muslims. That plague resulted in the dividedness of the Muslim community into two poles: member of the first pole were those who aspired to avoid the plague-infected land whereas the other did the opposite. Throughout the history of Islam, the patterns in approaching and responding to plagues tended to repeat themselves causing Muslims to have become divided into two groups: those who use rational and inductive reasoning on the one hand, and those who use textual deductive reasoning, on the other. 
What underlines the Muslims' response toward a plague seems to be the battle over authority between inductive scientific reasoning as represented by authoritative institutions on the one hand and the deductive textual reasoning as represented by religionists such as preachers and clerics, on the other. In the long run, in the way they lead Muslims in understanding the present pandemic, religionists seem to need to take inductive scientific reasoning into account in order for religion to comply with science. Despite the presence of a resistant attitude towards the pandemic, in the end, it is the government and its policies that decide its efforts to prevent the spread of the pandemic by adopting standardized medical protocols such as social and physical distancing, a stay-at-home policy, and the like. At this point, neither individuals nor institutions show their resistance towards the government policy in dealing with the plague.

\section{REFERENCES}

Adhey. (2020). Anak Buah Habib Rizieq Sebut Virus Corona Azab Kezaliman China Terhadap Islam Uighur. Pojoksatu.Id. https://pojoksatu.id/news/beritanasional/2020/01/25/anak-buah-habib-rizieq-sebutvirus-corona-azab-kezaliman-china-terhadap-islamuighur/

Agustin, M., Puspita, R. D., Nurinten, D., \& Nafiqoh, H. (2020). Tipikal Kendala Guru PAUD dalam Mengajar pada Masa Pandemi Covid 19 dan Implikasinya. Jurnal Obsesi: Jurnal Pendidikan Anak Usia Dini, 5(1), 334-345. 
Al-Asqalani, I. H. (1993). Badhl al-Ma'un fi Fadhl al-Ta'un. Dar al-Kutub al-Athariya.

Al-Suyuthi, J. al-D. (1997). Ma Rawahu al-Wa'un fi Akhbar alTa'un. Dar al-Kutub al-Misriyah.

Atsani, K. H. L. G. M. Z. (2020). Transformasi media pembelajaran pada masa Pandemi COVID-19. AlHikmah: Jurnal Studi Islam, 1(1), 82-93.

Barlow-Jones, G., \& van der Westhuizen, D. (2017). Problem solving as a predictor of programming performance. Annual Conference of the Southern African Computer Lecturers' Association, 209-216.

Byrne, Joseph P. (2012). Encyclopedia of the Black Death (Santa Barbara: ABC. CLIO, 88.

Byrne, Joseph Patrick. (2004). The black death. Greenwood Publishing Group.

Cantor, N. F. (2001). In the wake of the plague: the Black Death and the world it made. Simon and Schuster.

Conrad, L. I. (2017). A ninth-century Muslim scholar's discussion of contagion. In Contagion (pp. 163-177). Routledge.

Darmawan, D., Miharja, D., Waluyajati, R. S. R., \& Isnaeniah, E. (2020). Sikap Keberagamaan Masyarakat Menghadapi Wabah COVID-19. Religious: Jurnal Studi Agama-Agama Dan Lintas Budaya, 4(2), 115-124.

Dicker, G. (2004). Kant's theory of knowledge: An analytical introduction. Oxford University Press, USA. 
Dols, M. W. (2019). The black death in the middle east. Princeton University Press.

Fathurrahman, O. (2020). Sejarah Wabah Pandemi dan Narasi Agama-agama. Alif.Id.

Greenberg, R. (2010). Kant's theory of a priori knowledge. Penn State Press.

Hilmy, M. (2013). Induktivisme sebagai basis pengembangan ilmu pengetahuan dalam Islam. Ulumuna, 17(1), 97-126.

Iskandar, A., Possumah, B. T., \& Aqbar, K. (2020). Peran Ekonomi dan Keuangan Sosial Islam saat Pandemi Covid-19. Jurnal Sosial \& Budaya Syar'i FSH UIN Syarif Hidayatullah Jakarta, 7(7), 625-638.

Jahroni, J. (2020). Covid-19 dan Agama yang Pro-Sains. Uinjkt.Ac.Id.

Kathir, I. (1985). Al-Bidayah wa al-Nihayah. Dar Al-Kutub al-'Ilmiyah.

Kementerian Komunikasi dan Informatika Republik Indonesia. (2020). "[DISINFORMASI] Virus Corona Merupakan Senjata Biologis yang Bocor dari Laboratorium Wuhan. Kominfo.Go.Id.

Kendi Setiawan. (2020). Instruksi PBNU terkait Pencegahan Corona. Nu.or.Id. https://www.nu.or.id/post/ read/118239/instruksi-pbnu-terkait-pencegahan-corona

Kuipers, N., Mujani, S., \& Pepinsky, T. (2020). Encouraging Indonesians to Pray From Home During the COVID-19 Pandemic. Journal of Experimental Political Science, 1-12.

Ling, J. (2020). Report: The Wuhan Virus Is Not a Lab-Made Bioweapon. Foriegnpolicy.com 
Mansyur, A. R. (2020). Dampak covid-19 terhadap dinamika pembelajaran di indonesia. Education and Learning Journal, 1(2), 113-123.

Meri,J.W.(2005). Medieval Islamic civilization: an encyclopedia. Routledge.

Muhammad Abid Abid Al-Jabiri. (1993). Bunyah al-'Aql al'Arabi. al-Markaz al-Thaqafi al-'Arabi.

Muhammad Rizki Triyana. (2020). Virus Corona Musibah, Bukan Azab. Republika.Co.Id. https://republika.co.id/ berita/q74hkt467/virus-corona-musibah-bukan-azab

Mushodiq, M. A., \& Imron, A. (2020). Peran Majelis Ulama Indonesia Dalam Mitigasi Pandemi Covid-19 (Tinjauan Tindakan Sosial dan Dominasi Kekuasaan Max Weber). Salam: Jurnal Sosial Dan Budaya Syar-I, 7(5), 455-472.

Nagel, A., \&Wood, C.S.(2005). Toward a new model of renaissance anachronism. The Art Bulletin, 87(3), 403-415.

Naphy, W. G., \& Spicer, A. A. (2000). The Black Death: A History of the Plagues 1345-1730. Tempus.

Napitupulu, R. M. (2020). Dampak pandemi Covid-19 terhadap kepuasan pembelajaran jarak jauh. Jurnal Inovasi Teknologi Pendidikan, 7(1), 23-33.

Niam, A. M. (2020). Antara Corona, Ulama, dan Sains. Nu.or.Id.

Nuha, U. (2020). Sejarah Ummat Islam: Wabah Semakin Parah Setelah Berkumpul untuk Doa Bersama. Alif.Id. https:// alif.id/read/un/sejarah-umat-islam-wabah-semakinparah-setelah-berkumpul-untuk-doa-bersamab227416p/ 
Perho, I. (1997). The Prophet's medicine: A creation of the Muslim traditionalist scholars.

Person, S. (2010). Bubonic Plague: The Black Death! Bearport Publishing.

Putra, N. (2013). Hendarman, Metode Riset Campur Sari: Konsep, Strategi, dan Aplikasi. Jakarta: PT Indeks.

Ricklefs, M. C. (2007). Polarising Javanese society: Islamic and other visions, c. 1830-1930. NUS Press.

Rifa'i. (2020). 3 Suspect Corona Ditemukan Saat Tabligh Akbar, Ratusan Jemaah Lainnya Diisolasi. Indopolitika. Com. https://indopolitika.com/3-suspect-coronaditemukan-saat-tabligh-akbar-ratusan-jemaah-lainnyadiisolasi/

Rochim, A. (2020). Wabah Covid-19 dalam Pandangan Kiyai Said Aqil Siroj. Kalam.Sindonews.Com. https://kalam. sindonews.com/berita/1573141/69/wabah-covid-19dalam-pandangan-kiyai-said-aqil-siroj?showpage=all

Safari. (2020). Heboh Virus Corona Karena Azab. Harianterbit.Com. https://harianterbit.com/nasional/ read/119080/Heboh-Virus-Corona-Karena-Azab

Santoso, B., \& Aranditio, S. (2020). Maklumat Muhammadiyah Terkait Corona, Atur Salat dan Pengajian Saat Wabah. Suara.Com. https://www. suara.com/news/2020/03/16/074612/maklumatmuhammadiyah-terkait-corona-atur-salat-danpengajian-saat-wabah. 
Schellenberg, J. L. (2013). Evolutionary religion. OUP Oxford.

Scott, S., \& Duncan, C. J. (2004). Return of the black death: the world's greatest serial killer. John Wiley \& Sons.

Sean, A. (2020). UAS: Muslim Uyghur Dilindungi Tentara Allah SWT dari Virus, Namanya Tentara Corona. Indopolitika. Com. https://indopolitika.com/uas-muslim-uyghurdilindungi-tentara-allah-swt-dari-virus-namanyatentara-corona/

Silva Alhabsy. (2020). Pakar: Corona Harus Ditakuti, Bisa Jadi Senjata Biologi. News.Gunadarma.Ac.Id. http://news. gunadarma.ac.id/2020/03/090320/

Skinner, Q. (1969). Meaning and Understanding in the History of Ideas. History and Theory, 8(1), 3-53.

Stearns, J. (2008). Enduring the plague: Ethical behavior in the fatwas of a fourteenth-century mufti and theologian.

Stearns, J. (2009). New Directions in the Study of Religious Responses to the Black Death 1. History Compass, 7(5), 1363-1375.

Stearns, J. K. (2011). Infectious Ideas: Contagion in Premodern Islamic and Christian Thought in the Western Mediterranean. JHU Press.

Sumarni, Y. (2020). Pandemi Covid-19: Tantangan Ekonomi Dan Bisnis. Al-Intaj: Jurnal Ekonomi Dan Perbankan Syariah, 6(2), 46-58.

TV9 Official. (2020). Kajian Hikmah Agoes Ali Mashuri 11 Maret 2020 Bersama Sarung BHS. Youtube.Com. https://www. youtube.com/watch?v=HhZzNFt4kqY 
Varlik, N. (2015). Plague and empire in the early modern mediterranean world. Cambridge University Press.

Wirawan, M. K. (2020). Media Asing Sorot Jemaah Tabligh Indonesia: Kami Lebih Takut pada Tuhan. Kompas.Com.

Zaki, A. D. (2020). China, Virus Corona dan Pasukan Gajah! Hidayatullah.Com. https://www.hidayatullah.com/ artikel/mimbar/read/2020/01/26/176897/chinavirus-corona-dan-pasukan-gajah.html 